\title{
Pengaruh Dosis Pupuk Hayati Mikoriza terhadap Pertumbuhan dan Hasil pada Beberapa Varietas Tomat (Lycopersicum esculentum Mill.)
}

\author{
The Effect of Mycorrhizal Biofertilizer Dose on Growth and Yield in Some Tomato Varieties \\ (Lycopersicum esculentum Mill.)
}

\author{
Ridawati Pinayungan ${ }^{1}$, Mardhiah Hayati², Syafruddin² \\ ${ }^{1}$ Program Studi Agroteknologi PSDKU Gayo Lues, Fakultas Pertanian, Universitas Syiah Kuala \\ ${ }^{2}$ Program Studi Agroteknologi, Fakultas Pertanian, Universitas Syiah Kuala
}

\begin{abstract}
Abstrak. Penelitian ini bertujuan untuk mengetahui pengaruh dosis pupuk hayati mikoriza dan varietas tomat serta interaksi diantara keduanya terhadap pertumbuhan dan hasil tanaman tomat.Penelitian ini dilaksanakan di Kebun Percobaan dan Laboratorium Hortikultura Program Studi Agrotenologi Fakultas Pertanian Universitas Syiah Kuala, berlangsung dari bulan Juni sampai November 2019. Rancangan penelitian yang digunakan adalah Rancangan Acak Kelompok pola Faktorial 4 x 3 dengan 3 ulangan. Faktor yang diteliti yaitu dosis pupuk hayati mikoriza terdiri dari 4 taraf yaitu kontrol, 5,10 , dan $15 \mathrm{~g}_{\text {tanaman }}{ }^{-1}$ dan varietas yang terdiri dari 3 taraf yaitu, varietas lokal, Karina (Unggul) dan Rewako F1(Hibrida). Hasil penelitian menunjukkan bahwa, dosis pupuk hayati mikoriza berpengaruh sangat nyata terhadap tinggi tanaman pada umur $30 \mathrm{HST}$, diameter batang pada umur 15, 30, 45 HST dan peresentase kolonisasi mikoriza. Selanjutnya berpengaruh tidak nyata terhadap tinggi tanaman pada umur 45 HST, jumlah bunga umur 30, 35, 45, dan 50 HST, jumlah buah, berat buah per tanaman, dan potensi hasil. Pertumbuhan tanaman tomat terbaik adalah pada dosis pupuk hayati mikoriza $5 \mathrm{~g}$ tanaman ${ }^{-1}$, sedangkan hasil tanaman tomat dan persentase kolonisasi mikoriza yang terbaik adalah pada dosis pupuk hayati mikoriza $10 \mathrm{~g}$ tanaman ${ }^{-1}$. Perlakuan varietas berpengaruh sangat nyata terhadap tinggi tanaman umur 45 HST dan berat buah per tanaman, dan berpengaruh nyata terhadap tinggi tanaman umur 30 HST, diameter batang 15 HST, dan jumlah bunga 40 HST. Pertumbuhan tanaman tomat terbaik, pada varietas lokal, sedangkan hasil tanaman terbaik adalah pada varietas Rewako F1. Tidak terdapat interaksi yang nyata antara perlakuan dosis pupuk hayati mikoriza dan varietas terhadap pertumbuhan dan hasil tanaman tomat.
\end{abstract}

Kata kunci :Tomat, Pupuk hayati mikoriza, lokal, Karina dan Rewako F1

Abstract. This study aims to determine the effect of mycorrhizal biofertilizer dosages and tomato varieties as well as the interaction between them on the growth and yield of tomato plants. The research was carried out in the Experimental Garden and Horticulture Laboratory of the Agrotenology Study Program at the Faculty of Agriculture, Syiah Kuala University, taking place from June to November 2019. The research design used was a $4 \times 3$ factorial randomized block design with 3 replications. The research design used was a $4 \times 3$ factorial randomized block design with 3 replications. The factors studied were the dose of mycorrhizal biological fertilizer consisting of 4 levels, namely control, 5, 10, and 15 plants $^{-1}$ and varieties consisting of 3 levels namely, local varieties, Karina (Superior) and Rewako F1 ( Hybrid). The results showed that, the dose of mycorrhizal biofertilizer had a very significant effect on plant height at $30 \mathrm{HST}$, stem diameter at 15, 30, 45 HST and the percentage of mycorrhizal colonization. Furthermore, no significant effect on plant height at the age of 45 HST, the number of flowers aged 30,35, 45, and $50 \mathrm{HST}$, the number of fruits, fruit weight per plant, and yield potential. The best growth of tomato plants is at a dose of mycorrhizal biofertilizer $5 \mathrm{~g}$ plant-1, while the best yield of tomato plants and mycorrhizal colonization percentage is at a dose of mycorrhizal biological fertilizer 10 g plant-1. Varietal treatment significantly affected plant height at 45 HST and fruit weight per plant, and significantly affected plant height at $30 \mathrm{HST}$, stem diameter $15 \mathrm{HST}$, and number of flowers at $40 \mathrm{HST}$. The best tomato plant growth, in local varieties, while the best crop yields are in the Rewako F1 variety. There was no significant interaction between the treatment of mycorrhizal biofertilizer doses and varieties on the growth and yield of tomato plants.

Keywords:Tomato,Mycorrhizal biofertilizers, local, Karina and Rewako F1

\section{PENDAHULUAN}

Tanaman tomat (Lycopersicum esculentum Mill.) merupakan salah satu tanaman semusim dengan sifat pertumbuhannya perdu atau semak yang tumbuh di daerah tropis.Tomat tergolong sayuran buah multiguna dan multifungsi yang dapat dibudidayakan di lahan dataran 
rendah maupun di dataran tinggi. Buah tomatmengandung zat-zat yang berguna bagi kesehatan manusia antara lain mengandung vitamin C, vitamin A (karotien) dan mineral (Alamsyah dan Fitriyah, 2018). Pemanfaatan buah tomat adalah sebagai sayur, bumbu masak, bahan pewarna makanan, dan bahan kosmetik, selain itu sebagai bahan baku industri seperti saus, dan sari buah. Tomat dijadikan aneka olahan makanan ringan seperti manisan tomat, kripik, dan kerupuk tomat (Drakel, 2011).

Produksi tomat di Indonesia pada tahun 2016 sebanyak 883,2 ton, dan pada tahun 2017 mencapai 962,9 ton, terjadi peningkatan hasil setiap tahunnya. Seiring dengan bertambahnya jumlah penduduk, kebutuhan akan tomat semakin meningkat setiap tahunnya. Oleh karena itu perlu dilakukan usaha untuk meningkatkan produksi tomat melalui perbaikan tindakan agronomis (Badan Pusat Statistik, 2017).

Perbaikan tindakan agronomis yang diperlukan untuk meningkatkan hasil tomat yang tinggi diantaranya melalui penggunaan varietas unggul, terutama yang memiliki daya adaptasi yang baik terhadap lingkungan. Varietas unggul tanaman tomat dicirikan dengan produksi buah yang tinggi, respon terhadap pemupukan dan resisten terhadap hama dan penyakit tercermin dari keunggulan yang dimilikinya(Krisnawati et al., 2017).

Upaya untuk peningkatan produksi tomat dapat dilakukan dengan penggunaan pupuk hayati mikoriza dan varietas yang tepat. Pupuk hayati mikoriza dapat menambah unsur hara pada pertumbuhan tanaman. Mikoriza mampu meningkatkan pertumbuhan tanaman pada tingkat kesuburan tanah yang rendah. Mikoriza juga berfungsi untuk menginfeksi akar tanaman yang dapat memperoduksi jaringan hifa yang tumbuh dan dapat menembus lapisan sub soil, sehingga mampu meningkatkan pertumbuhan dan hasil tanaman cabai serta absorbsi unsur hara dan air (Syafruddin, 2016).

Mikoriza berasal dari bahasa Yunani yaitu myces yang berarti cendawan dan rhiza yang berarti akar. Mikoriza dikenal dengan istilah jamur tanah, karena hifa dan sporanya selalu berada di dalam tanah terutama di area rizosfer tanaman, jamur mikoriza juga memiliki kemampuan dalam memproduksi jalinan hifa eksternal, sehingga dapat menyerap unsur hara terutama fosfat menjadi lebih besar, sehingga dapat meningkatkan pertumbuhan dan produktivitas tanaman menjadi lebih baik. Aplikasi pupuk organik atau inokulan pupuk hayati yang efisien dan efektif diharapkan dapat meningkatkan pertumbuhan dan hasil buah tomat sekaligus menekan penggunaan pupuk kimia atau pestisida sintetis, sehingga akan menjamin dihasilkannya produk yang sehat dan menekan kerusakan lingkungan pembudidayaan tomat di lapangan (Wahyuni et al., 2013). Inokulan yang terdiri dari kombinasi antara spora, hifa, vesikel, dan arbuskel disebut dengan mikoriza campuran. Campuran mikoriza tesebut merupakan campuran dari genus Glomuse mossaea dan Gigaspora sp yang dikombinasikan antara keduanya (Rokhminarsidan Utami, 2011)

Hasil penelitian Ramaddan et al. (2018) perlakuan dosis mikoriza $10 \mathrm{~g}_{\operatorname{tanaman}^{-1}}$ berpengaruh sangat nyata terhadap berat basah tanaman, berat kering tanaman, berat kering akar tanaman, jumlah buah per tanaman, persentase infeksi mikoriza pada akar tanaman, dan hasil tanaman cabai merah juga memperoleh nilai tertinggi dengan produksi 9,18 ton ha-1,

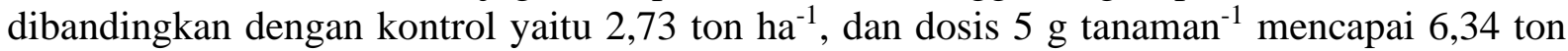
$\mathrm{ha}^{-1}$. Hal ini dikarenakan pada dosis mikoriza $10 \mathrm{~g}$ tanaman $^{-1}$ merupakan dosis optimum yang dapat menstimulasi pertumbuhan tanaman dan dapat meningkatkan hasil terhadap tanaman cabai.

Peningkatan dosis cendawan mikoriza arbuskula (CMA) dari dosis optimum $10 \mathrm{~g}$ $\operatorname{tanaman}^{-1}$ ditingkatkan menjadi $15 \mathrm{~g} \mathrm{tanaman}^{-1}$ dapat mempengaruhi penurunan hasil tanaman. Hal ini disebabkan bahwa CMA dalam bersiombiosis dengan tanaman juga membutuhkan karbohidrat yang diperoleh dari akar tanaman, apabila rasio unsur hara yang diserap oleh CMA terhadap karbohidrat yang dibutuhkan lebih kecil, maka akan mengakibatkan terjadinya penurunan hasil tanaman bawang merah (Saleh dan Atmaja. 2017). 
Upaya lain dalam meningkatkan hasil tomat dapat diperoleh dari penggunan varietas unggul. Varietas unggul memiliki daya adaptasi yang baik terhadap lingkungan, produksi buah yang tinggi, respon terhadap pemupukan dan resisten terhadap hama dan penyakit tercermin dari keunggulan yang dimilikinya. Varietas unggul cocok ditanam di dataran rendah atau medium, dan tahan terhadap layu bakteri (Hardianti et al., 2014). Varietas hibrida merupakan persilangan dua induk tomat galur murni yang memiliki sifat-sifat unggul. Varietas hibrida relatif lebih seragam dan memiliki potensi hasil yang tinggi (Wiryanta, 2007).

Tanaman tomat varietas Karina merupakan jenis benih unggul dengan tipe pertumbuhannya determinate, banyak varietas unggul tomat yang sudah dihasilkan pemulia atau produsen benih, varietas-varietas tersebut memiliki berbagai sifat yang berbeda satu sama lain seperti produksi, rasa, bentuk, umur panen, ketahanan simpan dan toleran terhadap penyakit tertentu. Karakteristik buah tomat varietas Karina memiliki bentuk buah bulat, seragam dan agak lembek (Salli dan Lehar, 2016). Tanaman tomat varietas Rewako F1 merupakan varietas hibrida, dapat tumbuh pada dataran menengah dan dataran rendah, varietas ini sering disebut masyarakat dengan tomat mawar, dimana bentuk buahnya seperti mawar (Hidayati dan Dermawan, 2012). Penelitian ini bertujuan untuk mengetahui pengaruh dosis pupuk hayati mikoriza dan beberapa varietas tomat serta interaksi antara kedua faktor tersebut terhadap pertumbuhan dan hasil tanaman tomat.

\section{METODE PENELITIAN}

Penelitian ini dilaksanakan di Kebun Percobaan dan Laboratorium Hortikultura, Fakultas Pertanian Universitas Syiah Kuala, Darussalam, Banda Aceh. Penelitian berlangsung pada bulan Juni sampai November 2019

\section{Alat dan Bahan Penelitian}

Alat-alat yang digunakan dalam penelitian ini ialah cangkul, trayer, kertas label, meteran, gembor, jangka sorong digital, tali rafia, pisau, gunting, ajir, timbangan analitik, mikroskop Nikon dengan pembesaran 100-400 kali, kamera dan alat tulis. Adapun bahan-bahan yang digunakan ialah benih tomat, polybag, mikoriza, pupuk NPK (16:16:16), pupuk kandang, pestisida bahan aktif Deltarmetrine, larutan $\mathrm{KOH}$, aquades dan larutan biru Ypan (Quink Parker).

\section{Rancangan Percobaan}

Penelitian ini menggunakan Rancangan Acak Kelompok (RAK) pola faktorial 3 x 4 dengan 3 ulangan, sehingga terdapat 12 kombinasi perlakuan dan 36 unit percobaan. Faktor yang diteliti adalah varietas dan dosis pupuk hayati mikoriza.Faktor pertama mikoriza dengan

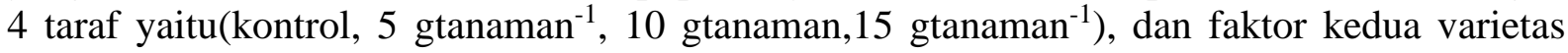
tomat dengan 3 taraf (lokal,Karina, Rewako F1) sehingga diperoleh 12 kombinasi perlakuan dan 36 unit percobaan, setiap percobaan trdiri dari 2 unit sehingga diperoleh 72 tanaman.

\section{Pelaksanaan Penelitian}

Persemaian dilakukan dengan menyiapkan tray yang telah diisi tanah dan pupuk kandang dengan perbandingan 1:1, kemudian menanamkan benih di tempat persemaian dan ditutup dengan tanah secara tipis, disiram pada sore hari.Pembibitan, dilakukan setelah benih mulai berkecambah kemudian dipindahkan ke polybag pembibitan. Media pembibitan dilakukan pada polybag dengan diameter $5 \mathrm{~cm}$ dan tinggi $7 \mathrm{~cm}$. Polybag yang telah berisi media disiram dengan air sampai kapasitas lapang dan bibit yang telah disemai dimasukkan ke dalam polybag sebanyak satu bibit per polybag. Diberikan mikoriza $1 / 2$ dosis pada 
pembibitan yaitu tanpa mikoriza (kontrol), 2,5 g, $5 \mathrm{~g}$, dan 7,5 g tanaman ${ }^{-1}$. Media tanam yang digunakan yaitu campuran tanah, pupuk kandang, dan sekam dengan perbandingan 2:1:1 (berdasarkan volume) yang dimasukkan ke dalam polybag berukuran $30 \mathrm{~cm}$ x $25 \mathrm{~cm}$ (volume $10 \mathrm{~kg}$ ). Selanjutnya setelah bibit berumur 21 hari setelah semai, bibit tersebut ke dalam polybag yang sudah disiapkan. Penanaman dilakukan dengan pemberian $1 / 2$ dosis lagi mikoriza dari masing-masing dosis yang ditentukan $\left(\mathrm{M}_{0}\right.$ : kontrol, $\mathrm{M}_{1}: 5 \mathrm{~g}$ tanaman ${ }^{-1}, \mathrm{M}_{2}: 10 \mathrm{~g}$ $\operatorname{tanaman}^{-1}$, dan $\mathrm{M}_{3}: 15 \mathrm{~g}_{\operatorname{tanaman}^{-1}}$ ), penanaman dilakukan pada sore hari.

Pemupukan dilakukan sebanyak 2 kali, pemupukan pertama diberikan pada saat setelah tanam dan pada umur 41 hari setelah tanam, pupuk dasar yang diberikan yaitu pupuk majemuk NPK Mutiara (16:16:16) sebanyak 50\% dari dosis anjuran yaitu 6,25 g polybag ${ }^{-1}$. Pemeliharaan tanaman tomat meliputi penyiraman, penyulaman, pemasangan ajir, pemangkasan, penyiangan gulma, dan pengendalian OPT. Penyiraman dilakukan sebanyak 2 kali sehari. Pemanenan buah tomat dilakukan pada saat tanaman berumur 65 HST. Pemanenan dilakukan pada saat tanaman tomat berumur 65 HST. Tanaman tomat sudah dikatakan siap panen apabila kulit buah berubah dari hijau menjadi kekuning-kuningan, bagian tepi daun menguning dan bagian batang mengering.

\section{Parameter Pengamatan}

Adapun parameter pengamatan adalah tinggi tanaman umur 15, 30, dan 45 HST, diameter batang umur 15, 30, dan 45 HST, jumlah bunga per tanaman umur 30, 35, 40, 45 , dan 50 HST, jumlah total buah per tanaman umur 65 HST, bobot buah per tanaman, potensi hasil dan persentase akar terkolonisasi mikoriza (\%)

$$
\text { Potensi hasil }\left(\frac{\text { ton }}{\text { ha }}\right)=\frac{\text { Luas lahan }-20 \%}{\text { Jarak tanam }} \times \text { Hasil per tanaman }
$$

\section{Persentase Akar Terkolonisasi Mikoriza (\%)}

Setelah tanaman umur 45 hari setelah pindah tanam akar tanaman yang terinfeksi mikoriza menggunakan mikroskop Nikon dengan langkah-langkah sebgai berikut :

1. Tanaman yang diamati adalah tanaman sampel yang berumur 45 HST. Tanaman yang mendapatkan perlakuan dicabut dan diambil akarnya.

2. Akar tanaman dicuci dengan air aquades sampai bersih, kemudian dipotong ukuran 1 $\mathrm{cm}$ dan direndam dengan $10 \%$ larutan $\mathrm{KOH}$ selama 24 jam untuk memutihkan akar.

3. Kemudian akar direndam dengan menggunakan larutan biru ypan (Quink Parker) selama 24 jam

4. Melakukan perendaman kembali dengan menggunakan air bersih (aquades) agar bersih dari warna tinta.

5. Mengambil 5 rumpun akar per tanaman tomat secara acak kemudian diletakkan pada kaca preparat, lalu diamati dengan menggunakan mikroskop Nikon dengan pembesaran 100-400 kali, kemudian menghitung persentase dengan menggunakan rumus :

$$
\text { Akar terkolonisasi }(\%)=\frac{\text { Jumlah akar yang terkolonisasi mikoriza }}{\text { Jumlah akar yang diamati }} \times 100 \%
$$




\section{HASIL DAN PEMBAHSAN}

\section{Pengaruh Dosis Pupuk Hayati Mikoriza Terhadap Pertumbuhan dan Hasil Tomat}

Hasil uji $\mathrm{F}$ pada analisis sidik ragam menunjukkan bahwa dosis pupuk hayati mikoriza berpengaruh sangat nyata terhadap tinggi tanaman pada umur 30 HST, diameter batang pada umur 15, 30, dan $45 \mathrm{HST}$, serta pada peubah persentase kolonisasi mikoriza, akan tetapi berpengaruh nyata terhadap tinggi tanaman umur 15 HST, dan jumlah bunga umur 40 HST. Selanjutnya dosis pupuk hayati mikoriza berpengaruh tidak yata terhadap tinggi tanaman pada umur 45 HST, jumlah bunga umur 30, 35, 45, dan 50 HST, kemudian pada peubah jumlah buah, berat buah per tanaman, dan potensi hasil. Rata-rata pertumbuhan dan hasil tanaman tomat akibat perlakuan dosis pupuk hayati mikoriza dilihat pada Tabel 1 .

Tabel 1. Rata-rata Pertumbuhan dan Hasil Tanaman Tomat Akibat Dosis Pupuk Hayati Mikoriza

\begin{tabular}{|c|c|c|c|c|c|c|}
\hline \multirow{2}{*}{ Parameter } & & \multicolumn{4}{|c|}{ Mikoriza $\left(\mathrm{g} \operatorname{tanaman}^{-1}\right)$} & \multirow{2}{*}{$\mathrm{BNJ}$} \\
\hline & & Kontrol & 5 & 10 & 15 & \\
\hline \multirow{3}{*}{ Tinggi Tanaman $(\mathrm{cm})$} & $15 \mathrm{HST}$ & $43,90 \mathrm{ab}$ & $53,07 \mathrm{c}$ & $40,93 \mathrm{a}$ & $48,97 \mathrm{~b}$ & 6,79 \\
\hline & $30 \mathrm{HST}$ & $108,67 \mathrm{a}$ & $136,07 \mathrm{~b}$ & $92,03 \mathrm{a}$ & $129,33 \mathrm{ab}$ & 18,73 \\
\hline & $45 \mathrm{HST}$ & 155,93 & 175,5 & 143,1 & 167 & - \\
\hline \multirow{3}{*}{ Diameter Batang (mm) } & 15 HST & $8,67 \mathrm{a}$ & $11,16 \mathrm{c}$ & $7,99 \mathrm{a}$ & $10,57 \mathrm{ab}$ & 1,49 \\
\hline & $30 \mathrm{HST}$ & $17,64 \mathrm{~b}$ & 20,99 c & $14,48 \mathrm{a}$ & $19,84 \mathrm{~b}$ & 2,60 \\
\hline & $45 \mathrm{HST}$ & $22,15 \mathrm{a}$ & $25,56 \mathrm{~b}$ & $20,21 \mathrm{a}$ & $25,10 \mathrm{ab}$ & 2,62 \\
\hline \multirow{7}{*}{ Jumlah Bunga (buah) } & $30 \mathrm{HST}$ & $\begin{array}{c}5,67 \\
(4,81)\end{array}$ & $\begin{array}{l}12,00 \\
(6,68)\end{array}$ & $\begin{array}{c}4,33 \\
(4,77)\end{array}$ & $\begin{array}{c}8,00 \\
(5,83)\end{array}$ & 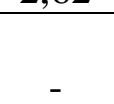 \\
\hline & 35 HST & 23,67 & 41,00 & 16,67 & 24,00 & \\
\hline & & $(8,37)$ & $(10,63)$ & $(7,18)$ & $(8,67)$ & - \\
\hline & $40 \mathrm{HST}$ & 32,33 & 55,67 & 24,00 & 41,33 & \\
\hline & & $(9,83) \mathrm{a}$ & $(12,68) b$ & $(9,71) \mathrm{a}$ & $(11,15) a b$ & 1,75 \\
\hline & 45 HST & 12,84 & 15,09 & 13,19 & 12,71 & - \\
\hline & $50 \mathrm{HST}$ & 13,52 & 14,87 & 13,40 & 12,98 & - \\
\hline \multicolumn{2}{|l|}{ Jumlah Buah 8x Panen } & $\begin{array}{l}23,00 \\
(8,23)\end{array}$ & $\begin{array}{l}26,97 \\
(8,78)\end{array}$ & $\begin{array}{l}29,67 \\
(9,34)\end{array}$ & $\begin{array}{l}23,00 \\
(8,10)\end{array}$ & - \\
\hline \multirow{2}{*}{\multicolumn{2}{|c|}{$\begin{array}{l}\text { Berat Buah per } \\
\text { Tanaman }(\mathrm{g})\end{array}$}} & 419,24 & 529,92 & 607,78 & 403,95 & \\
\hline & & $(34,91)$ & $(38,31)$ & $(41,93)$ & $(34,45)$ & - \\
\hline \multicolumn{2}{|l|}{ Potensi Hasil (ton ha ${ }^{-1}$ ) } & $\begin{array}{c}3,50 \\
(1,85)\end{array}$ & $\begin{array}{c}4,78 \\
(2,10) \\
\end{array}$ & $\begin{array}{c}5,26 \\
(2,24) \\
\end{array}$ & $\begin{array}{c}3,13 \\
(1,72) \\
\end{array}$ & - \\
\hline \multicolumn{2}{|l|}{ Persentase Kolonisasi } & 0,00 & 37,78 & 42,22 & 40,00 & \\
\hline \multicolumn{2}{|c|}{ Mikoriza $(\%)$} & $(1,28) \mathrm{a}$ & $(37,70) \mathrm{b}$ & $(40,26) b$ & $(38,98) \mathrm{b}$ & 15,63 \\
\hline \multicolumn{7}{|c|}{$\begin{aligned} & \text { Keterangan: - } \text { Angka yang diikuti oleh huruf yang sama pada kolom yang sama berbeda tidak nyata pada taraf } \\
& 5 \%\left(\text { Uji BNJ }_{0,05}\right) \\
&- \text { ( ) Angka yang sudah transformasi : jumlah buah per tanaman, berat buah per tanaman, dan } \\
& \text { potensi hasil menggunakan teransformasi data }(\sqrt{x}) \text {, jumlah bunga menggunakan tranformasi }\end{aligned}$} \\
\hline & & & & & & $\sqrt{\frac{1}{4 n} \%}$ \\
\hline
\end{tabular}

Hasil penelitian menunjukkan bahwa tinggi tanaman tomat umur 15 dan 30 HST, tanaman tertinggi dijumpai pada perlakuan dosis pupuk hayati mikoriza $5 \mathrm{~g} \mathrm{tanaman}^{-1}$ yang

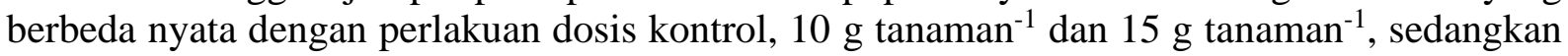
tinggi tanaman tomat umur 45 HST cenderung tertinggi dijumpai pada perlakuan dosis $5 \mathrm{~g}$ $\operatorname{tanaman}^{-1}$ yang berbeda tidak nyata dengan perlakuan kontrol, $10 \mathrm{~g} \operatorname{tanaman}^{-1}$ dan $15 \mathrm{~g}$ $\operatorname{tanaman}^{-1}$. 
Diameter batang tanaman ${ }^{-1}$ tomat umur 15, 30 dan 45 HST terbesar dijumpai pada dosis $5 \mathrm{~g}$ tanaman $^{-1}$ yang berbeda nyata dengan perlakuan kontrol, $10 \mathrm{~g} \operatorname{tanaman}^{-1}$ dan $15 \mathrm{~g}$ $\operatorname{tanaman}^{-1}$. Jumlah bunga tanaman tomat umur 40 HST terbanyak dijumpai pada perlakuan dosis $5 \mathrm{~g}_{\text {tanaman }}{ }^{-1}$ yang berbeda nyata dengan perlakuan kontrol, $10 \mathrm{~g} \operatorname{tanaman}^{-1}$ dan $15 \mathrm{~g}$ $\operatorname{tanaman}^{-1}$, serta jumlah bunga tanaman tomat umur 30, 35, 45 dan 50 HST cenderung terbesar dijumpai pada perlakuan dosis $5 \mathrm{~g}^{\text {tanaman }^{-1}}$ yang berbeda tidak nyata dengan perlakuan kontrol, $10 \mathrm{~g}_{\text {tanaman }}{ }^{-1}$ dan $15 \mathrm{~g}_{\text {tanaman. }}{ }^{-1}$

Jumlah buah per tanaman tomat cenderung terbanyak dijumpai pada perlakuan dosis $10 \mathrm{~g} \mathrm{tanaman}^{-1}$ yang berbeda tidak nyata dengan perlakuan kontrol, $5 \mathrm{~g} \operatorname{tanaman}^{-1}$ dan $15 \mathrm{~g}$ $\operatorname{tanaman}^{-1}$. Berat buah tanaman tomat dan potensi hasil cenderung tertinggi dijumpai pada perlakuan dosis $10 \mathrm{~g} \mathrm{tanaman}^{-1}$ yang berbeda tidak nyata dengan perlakuan kontrol, $5 \mathrm{~g}$ $\operatorname{tanaman}^{-1}$ dan $15 \mathrm{~g}$ tanaman $^{-1}$. Persentase kolonisasi mikoriza cenderung tertinggi dijumpai pada dosis $15 \mathrm{~g}_{\text {tanaman }}{ }^{-1}$ yang berbeda tidak nyata dengan perlakuan $5 \mathrm{~g} \operatorname{tanaman}^{-1}$ dan $10 \mathrm{~g}$ tanaman-1.

Hasil penelitian menunjukkan bahwa tinggi tanaman, diameter batang, dan jumlah bunga yang terbaik dijumpai pada dosis pupuk hayati mikoriza $5 \mathrm{~g} \operatorname{tanaman}^{-1}$. Hal ini diduga hifa eksternal mikoriza dapat dapat membantu penyerapan air dan unsur-unsur hara yang digunakan dalam proses matbolisme di dalam organ tanaman sehingga dapat memacu pertumbuhan tanaman. Hasil penelitian ini sesuai dengan hasil penelitian Sumiati dan Gunawan (2007) pemberian pupuk hayati mikoriza dengan dosis $5 \mathrm{~g} \operatorname{tanaman}^{-1} \operatorname{tanpa}$ adanya penambahan pupuk kimia NPK (15-15-15) dapat menghasilkan kandungan unsur hara K tanaman bawang merah yang tinggi, disebabkan karena aktivitas cendawan mikoriza yang terkandung dalam formula hayati yang mengandung spesies-sesies mikoriza.

Penelitian ini menunjukkan bahwa pemberian pupuk hayati mikoriza dengan dosis 10 $\mathrm{g} \operatorname{tanaman}^{-1}$ mempeoleh nilai yang terbaik dalam berat buah per tanaman yaitu 607,78 $\mathrm{g}$ tanaman $^{-1}$ dibandingkan dengan dosis lainnya, hal ini diduga karena selain pemberian mikoriza, penyiraman tanaman tomat dengan air secara teratur juga mempengaruhi untuk meningkatkan berat buah tomat. Hal ini juga ditemukan dalam penelitian Berman dan Dejong (1996) air sangat memiliki peranan yang penting dalam proses pembuahan, kekurangan air dapat menurunkan bobot buah cabai. Murniati et al. (2008) pemberian CMA $10 \mathrm{~g}$ tanaman $^{-1}$ dapat memberikan bobot umbi per rumpun bawang merah terbaik pada lahan gambut. Hifa eksternal pada mikoriza berfungsi untuk menyerap unsur hara terutama unsur $\mathrm{P}$ dan $\mathrm{K}$ yang berpengaruh terhadap bobot buah tanaman cabai merah (Suherman et al., 2007).

Hasil penelitian ini menunjukkan bahwa infeksi kolonisasi mikoriza terbaik dijumpai pada dosis pupuk hayati mikoriza $10 \mathrm{~g}_{\text {tanaman }}^{-1}$. Hal ini diduga proses infeksi mikoriza dipengaruhi oleh faktor iklim dan faktor tanah, terutama intensitas matahari sangat berpengaruh terhadap perkembangan mikoriza serta keberhasilan simbiosisnya dengan inang. Hal ini juga ditemukan dalam penelitian Syafruddin et al. (2017) yang menyatakan bahwa infeksi akar mikoriza pada akar tanaman cabai tertinggi dijumpai pada dosis mikoriza $10 \mathrm{~g}$ tanaman $^{-1}$. Penelitian Sampurno et al. (2010) menyatakan akar tanaman yang terinfeksi oleh mikoriza memungkinkan tanaman akan menyerap unsur hara yang banyak, dengan adanya mikoriza perakaran lebih mudah berkembang dan memanjang karena dapat mengemburkan tanah disekitar tanaman, sehingga meningkatkan penyerapan unsur hara dimana akar yang bermikoriza dapat meningkatkan penyerapan posfor dan unsur hara lainnya.

\section{Pengaruh Varietas terhadap Pertumbuhan dan Hasil Tanaman Tomat}

Hasil uji $\mathrm{F}$ pada analisis sidik ragam (Lampiran 1) menunjukkan bahwa perlakuan varietas berpengaruh sangat nyata terhadap tinggi tanaman umur $45 \mathrm{HST}$, dan berat buah per tanaman, akan tetapi berpengaruh nyata terhadap tinggi tanaman umur 30 HST, diameter 
batang 15 HST, jumlah bunga dan 40 HST. Selanjutnya varietas tidak berpengaruh nyata terhadap tinggi tanaman umur 15 HST, diameter batang umur 30, dan 45 HST, jumlah bunga umur 30, 35, 45, dan $50 \mathrm{HST}$, jumlah buah, potensi hasil ton ha ${ }^{-1}$, dan persentase kolonisasi mikoriza. Rata-rata pertumbuhan dan hasil tanaman tomat akibat perlakuan varietas dapat dilihat pada Tabel 2.

Tabel 2. Rata-rata Pertumbuhan dan Hasil Tanaman Tomat Akibat Perlakuan Varietas

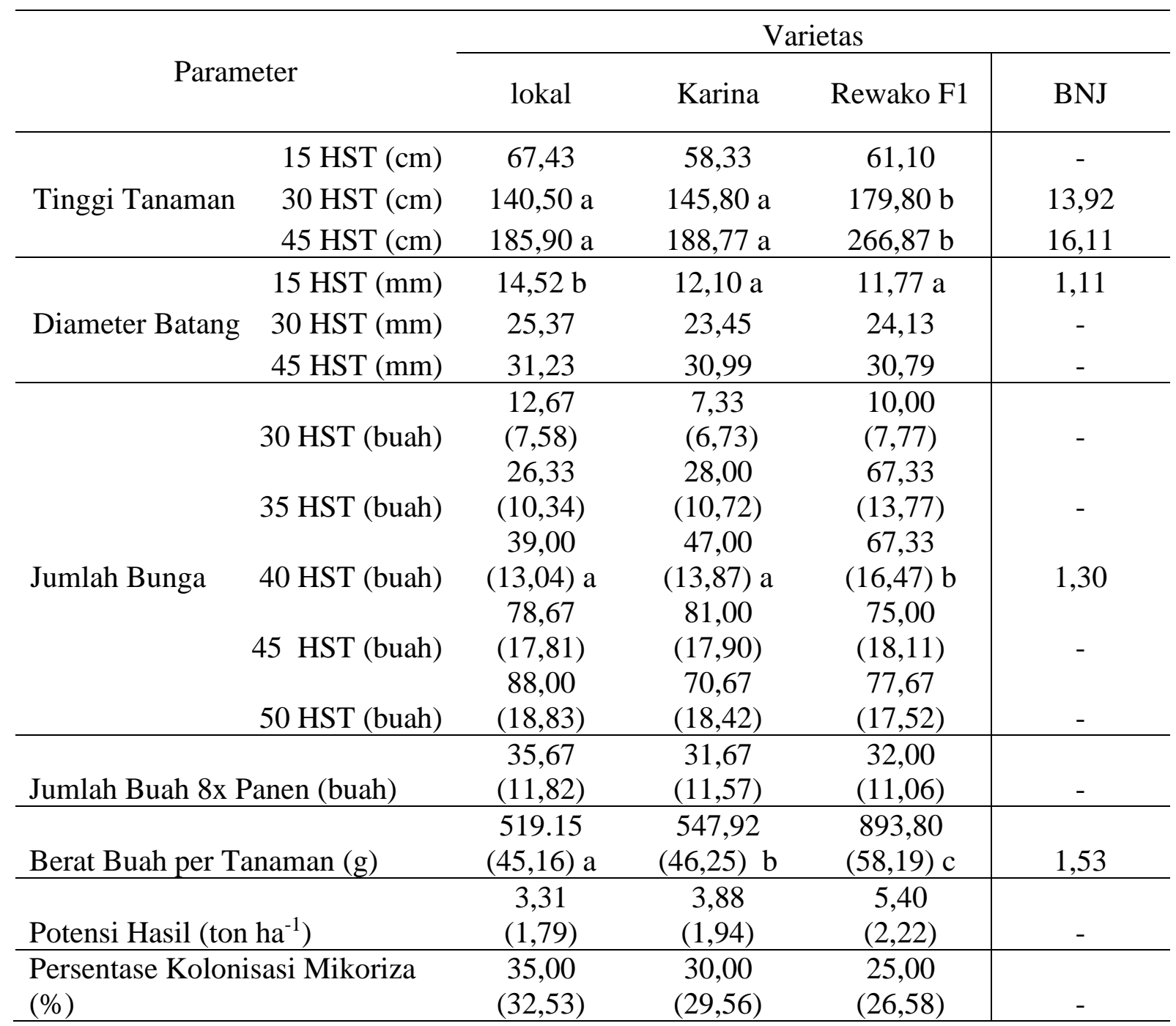

Keterangan: - Angka yang diikuti oleh huruf yang sama pada kolom yang sama berbeda tidak nyata pada taraf $5 \%$ (Uji BNJ 0,05$)$

( ) Angka yang sudah transformasi : jumlah buah per tanaman, berat buah per tanaman, potensi hasil teransformasi data $(\sqrt{x})$, jumlah bunga tranformasi data menggunakan $\sqrt{\mathrm{x}+0,5}$, dan persentase kolonisasi mikoriza $x=\operatorname{archin} \sqrt{\frac{1}{4 n} \%}$

Tabel 2 menunjukkan bahwa umur 30, dan 45 HST tertinggi dijumpai pada perlakuan varietas Rewako F1 yang berbeda nyata dengan perlakuan varietas lokal dan Karina, serta tinggi tanaman umur 15 HST cenderung tertinggi dijumpai pada perlakuan varietas Rewako F1 yang berbeda tidak nyata dengan perlakuan varietas lokal dan Karina. Diameter batang tanaman tomat umur 15, 30 dan 45 HST cenderung terbesar dijumpai pada perlakuan varietas lokal berbeda tidak nyata dengan perlakuan varietas Karina dan Rewako F1.

Jumlah bunga tanaman tomat umur 40 HST terbanyak dijumpai pada perlakuan varietas Rewako F1 yang berbeda nyata dengan perlakuan varietas lokal dan Karina, pada umur 30, 
35, dan 45 HST jumlah bunga tanaman tomat cenderung terbanyak dijumpai pada varietas perlakuan varietas Rewako F1 yang berbeda tidak nyata dengan perlakuan varietas lokal dan Karina, serta jumlah bunga tanaman umur 50 HST cenderung tertinggi dijumpai pada varietas lokal yang berbeda tidak nyata dengan perlakuan varietas Karina dan Rewako F1.

Jumlah buah tanaman tomat cenderung terbanyak dijumpai pada perlakuan varietas lokal yang berbeda tidak nyata dengan perlakuan varietas Karina dan Rewako F1. Berat buah tanaman tomat tertinggi dijumpai pada varietas Rewako F1 yang berbeda sangat nyata dengan varietas lokal dan Karina. Potensi hasil tanaman tomat tertinggi dijumpai pada perlakuan varietas Rewako F1 yang berbeda nyata dengan perlakuan varietas lokal dan Karina.Persentase kolonisasi mikoriza cenderung tertinggi dijumpai pada perlakua varietas Karina yang berbeda tidak nyata dengan perlakuan varietas loka dan Rewako F1.

Penelitian ini menunjukkan bahwa tinggi tanaman, diameter batang, berat buah per tanaman, dan jumlah bunga terbaik dijumpai pada varietas Rewako F1. Hal ini di duga bahwa varietas ini selain dikenal dengan pertumbuhannya yang determinate, diduga juga karena serapan unsur hara diberikan lebih cepat berefektivitas dari pada varietas lainnya. Setiap varietas memiliki kemampuan menyerap nutrisi yang berbeda, sehingga berdampak terhadap pertumbuhan dan hasil yang berbeda. Faktor biotik seperti air, tanah, dan iklim merupakan faktor yang mempengaruhi pertumbuhan varietas tanaman (Budianto et al ., 2014).

Faktor lingkungan dapat mempengaruhi proses terbentuknya bunga salah satunya faktor akibat suhu. Suhu secara langsung mempengaruhi proses fotosintesia, respirasi, absorbsi air unsur hara serta transpirasi. Suhu yang baik untuk pertumbuhan tomat adalah $18^{\circ} \mathrm{C}-25^{\circ} \mathrm{C}$. Suhu harian yang melebihi batas optimum pada tanaman dapat mempercepat proses terjadinya pembungaan. Kondisi ini disebabkan karena tanaman akan lebih cepat mengumpulkan satuan panas sehingga berdampak pada lebih cepatnya tanaman untuk membentuk bunga dan memiliki jumlah bunga yang lebih tinggi (Wiryanta, 2002).

Pertumbuhan vegetatif dan generatif tanaman tomat dapat dipengaruhi oleh faktor genetik dan lingkungan. Dalam penelitian ini menunjukkan bahwa sifat genetik varietas lebih berpengaruh dari pada faktor lingkungan, diduga karena perbedaan genetik antar varietas. Hal ini sesuai dengan pendapat Salli dan Lehar (2016), bahwa perbedaan genetik pada tanamantanaman tersebut menyebabkan perbedaan dalam pembentukan enzim sebagai katalisator proses metabolisme tanaman, dan perbedaan varietas dapat mengakibatkan adanya perbedaan gen pengatur yang mempengaruhi tingkat pertumbuhan dan perkembangan tanaman.

Hal ini dapat disebabkan varietas Rewako F1 memberikan ukuran buah yang lebih besar dibandingkan dengan varietas lainnya yang hanya ukuran buahnya kecil, besar kecilnya buah tomat dapat mempengaruhi bobot buah per tanamannya dilihat dari penelitian ini bobot buah varietas Rewako F1 yaitu 893,80 $\mathrm{g}_{\text {tanaman }}{ }^{-1}$ sedangkan varietas lokal 519,15 g $\operatorname{tanaman}^{-1}$ dan Karina yaitu 547,92 $\mathrm{g} \mathrm{tanaman}^{-1}$. Hidayati dan Dermawan (2012) menyatakan bahwa bobot buah varietas Rewako F1 dapat mencapai 40-50 $\mathrm{g} \mathrm{buah}^{-1}$, dan potensi hasil lebih dari $2,6 \mathrm{k} \mathrm{g}$ tanaman $^{-1}$.

\section{KESIMPULAN}

Perlakuan dosis mikoriza berpengaruh sangat nyata pada parameter tinggi tanaman diameter batang, jumlah bunga, dan persentase kolonisasi mikoriza. Pertumbuhan tanaman tomat terbaik adalah pada dosis pupuk hayati mikoriza $5 \mathrm{~g} \operatorname{tanaman}^{-1}$, sedangkan hasil tanaman tomat dan persentase kolonisasi mikoriza yang terbaik adalah pada dosis pupuk hayati mikoriza $10 \mathrm{~g} \operatorname{tanaman}^{-1}$. Perlakuan varietas berpengaruh sangat nyata terhadap tinggi tanaman umur 45 HST, dan berat buah per tanaman. Selain itu varietas berpengaruh nyata terhadap tinggi tanaman umur 30 HST, diameter batang umur 15 HST, dan jumlah bunga umur 40 HST. Pertumbuhan tanaman tomat terbaik, pada varietas lokal, sedangkan hasil tanaman terbaik adalah pada varietas Rewako F1. Interaksi antara dosis pupuk hayati 
mikoriza dengan varietas berpengaruh tidak nyata terhadap pertumbuhan dan hasil tanaman tomat.

\section{DAFTAR PUSTAKA}

Alamsyah, A.R. F., dan N. Fitriyah. 2018. Pengaruh mikoriza dan EM4 terhadap pertumbuhan dan produktivitas tanaman tomat (Solanum lycopersicum). Jurnal Ilmiah Hijau Cendekia. 3(1):14-19.

Badan Pusat Statistik. 2017. Produktivitas Tomat Indonesia tahun 2016-2017. Jakarta. http://jakarta. litbnag.pertanian.go.id/ind/phocadownload/tomat.pdf.Diakses pada tanggal 02 Mei 2019.

Berman, M. E., dan T. M. Dejong. 1996. Water Stress and Crop Load Effects on Fruit Fres and Dray weights In Peach (Prumus persica). Tree Physiologi 16:859-864.

Budianto, P. T. H., R. Wirooedarmo, dan B. Suharto. 2014. Perbedaan laju interaksi pada lahan hutan tanaman industri pinus, jati, dan maharoni. Jurnal Sumberdaya Alam dan Lingkungan. Hal:15-24.

Drakel, A. 2011.Kajian usaha tani tanaman tomat terhadap produksi dan pendapatan petani (StudiKasus di Desa Golago Kusuma, Kecamatan Jailolo Timur, Kabupaten Halmahera Barat).Jurnal Ilmiah Agribisnis dan Perikanan. 4 (2): 31-35.

Hardianti, R. A., S. R.Yuni. dan T. A. Mahanani. 2014. Efektivitas waktu pemberian Trichoderma harzianum dalam mengatasi serangan layu Fusarium pada tanaman tomat varietas Ratna. LenteraBio. 3(1): 21-25.

Hidayati, N. dan R. Dermawan. 2012. Tomat Unggul. Penebar Swadaya. Jakarta.

Krisnawati, S., M. T. Darini, dan Darnawi. 2017. Pengaruh komposisi media tanam dan dosis pupuk kascing terhadap pertumbuhan dan hasil tanaman tomat varietas intan(Solanum lycopersicum Mill.). Skripsi. Fakultas Pertanian Sarjanawiyata Tanamsiswa, Yoyakarta.

Murniati, A.N., Yulia, dan F. Silvina. 2008. Peningkatan produksi bawang merah dengan agihancendawan mikoriza arbuskula dan $\mathrm{Cu}$ pada lahan gambut. Sagu. 7(1): 19-25.

Ramaddan, I., Syafruddin dan Jumini. 2018. Pengaruh dosis mikoriza terhadappertumbuhan dan hasil varietas cabai (Capsicum annum L.) pada tanah inceptisol krueng kaya Ace Besar. Skripsi. Program Studi Agroteknologi. Fakultas Pertanian. Universitas Syiah Kuala, Banda Aceh.

Rokhminarsi, E., Begananda dan D. S. Utami. 2011. Indentifikasi mikoriza spesifik lokasi lahan marginal pada rizosfer tanaman hortikultura. Laporan Penelitian Fakultas Pertanian Unsoed, Purwokerto.

Sampurno, Elsie dan O. Riana. 2010. Pemanfaatan cendawan mikoriza arbuskula (CMA) Padabeberapa jenis tanah terhadap pertumbuhan kacang tana (Arachis hipogea L.). Sagu.9(1):28-37.

Salli, M. K., dan L. Lehar. 2016. Respons pertumbuhan beberapa varietas tomat (Lycopersicum esculentum Mill.) yang diaplikasikan plant growth promoting rhizobacteria (PGPR) di lahan kering. Partner. 22(1): 431-433. 
Sumiati, E. dan O.S. Gunawan. 2007. Aplikasi pupuk hayati mikoriza untuk meningkatkan efesiensi serapan unsur hara NPK serta pengaruhnya terhadap hasil dan kualitas umbi bawang merah. Juranal Hort. 17(1) : 34-42.

Suherman, C., A. Nuraini., dan S. Rosiniawaty. 2007. Pemanfaatan cendawan mikoriza arbuskula (CMA) serta media campuran subsoil dan kompos pada pembibitan kelapa sawit (Elais gueniensis) kultivar sungai pancur 2 (SP2). Skripsi. Fakultas Pertanian. Universitas Padang, Padang.

Syafruddin, S. Syakur dan Hasanuddin. 2017. Teknik perbanyakan pupuk hayati mikoriza dan adopsi inovasi sebagai bioferilizer dan bioprotektor untuk peningkat produksi cabai pada Inceptisol Krueng Raya Aceh Besar. Laporan Akhir Penelitian Berbasis Kompetensi.Universitas Syiah Kuala, Banda Aceh.

Syafruddin. 2016. Growth and yield of chili pepper (Capsicum annum L.) on the growing media of entisol Aceh using varios endomycorrhizae. Int. J. Agriculture Rearch. 12(1): $36-40$.

Wahyuni, S., L. Riza., dan K. Siti. 2013. Pengaruh inokulum jamur glomus aggregatum dan pupuk fosfat Sp-36 terhadap pertumbuhan tanaman tomat (Lycopersicum esculentum, Mill.) pada tanah gambut. Jurnal Protobiont. 2 (3): 152-156.

Wiryanta. 2002. Bertanaman Cabai pada Musim Hujan. Agromedia Pustaka. Jakarta.

Wiryanta, B.T.W. 2007. Bertanam Tomat. Agromedia Pustaka. 102 hlm. Jakarta. 